\title{
Ovarian and luteal blood flow, and peripheral plasma progesterone levels, in cyclic guinea-pigs
}

\author{
M. I. Hossain, C. S. Lee, I. J. Clarke* and J. D. O'Shea \\ Department of Veterinary Preclinical Sciences, University of Melbourne, Parkville, \\ Victoria 3052, and \\ *Reproduction Research Section, University of Melbourne, Animal Research Institute, \\ Werribee, Victoria 3030, Australia
}

\begin{abstract}
Summary. Ovarian and luteal blood flow rates were studied using radioactive microspheres in guinea-pigs between Day 6 of the oestrous cycle and Day 1 of the following cycle. Peripheral plasma progesterone levels were measured by radioimmunoassay on the same days of the oestrous cycle.

Ovarian blood flow was greatest between Days 9 and 12 and had fallen by Day 16 both in absolute $\left(\mathrm{ml} \cdot \mathrm{min}^{-1}\right)$ and relative $\left(\mathrm{ml} \cdot \mathrm{min}^{-1} \cdot \mathrm{g}^{-1}\right)$ terms. Luteal weight and blood flow were also greatest between Days 9 and 12 and had fallen sharply by Day 16. The highest mean ( \pm s.d.) luteal flows measured were $0.10 \pm 0.04 \mathrm{ml} \cdot \mathrm{min}^{-1}$ per corpus luteum, and $24.26 \pm 9.3 \mathrm{ml} \cdot \mathrm{min}^{-1} \cdot \mathrm{g}^{-1}$ luteal tissue on Day 10 of the cycle. Mean peripheral plasma progesterone levels reached a maximum of $3.66 \pm$ $1.1 \mathrm{ng} / \mathrm{ml}$ at Day 12 of the cycle and fell thereafter, reaching $0.74 \pm 0.5 \mathrm{ng} / \mathrm{ml}$ by Day 1 of the following cycle. Plasma progesterone levels declined significantly between Days 12 and 14 of the cycle, whereas no significant drop in luteal blood flow was demonstrable until after Day 14. These data do not support the idea that declining luteal blood flow is an initiating mechanism in luteal regression in the guinea-pig.
\end{abstract}

\section{Introduction}

Luteal tissue has been shown to receive a very high blood flow in sheep (Thorburn \& Hales, 1972; Niswender, Diekman, Nett \& Akbar, 1973) and rabbits (Novy, 1972; Abdul Karim \& Bruce, 1973; Janson \& Albrecht, 1975), with total ovarian flow rates being highest at times when functional corpora lutea are present. Both luteal and total ovarian flow rates fall sharply around the time of luteal regression (Abdul Karim \& Bruce, 1973; Niswender, Moor, Akbar, Nett \& Diekman, 1975; Bruce \& Moor, 1976).

Since Pharriss \& Wyngarden (1969) originally proposed that luteal regression might be caused by a reduction in luteal blood flow, the significance of declining blood flow in the process of luteolysis has remained controversial. Niswender, Reimers, Diekman \& Nett (1976) concluded that blood flow to the corpus luteum may be important in the regulation of luteal function, including changes occurring during luteal regression. However, other workers including Rathmacher \& Anderson (1968) in the pig, Bruce \& Hillier (1974) in the rabbit, and McCracken, Glew \& Scaramuzzi (1970) and Baird (1974) in the sheep, have argued against a vascular mechanism of luteolysis, because declining blood flow could not be shown to precede the fall in progesterone secretion during luteal regression.

The guinea-pig has been an important experimental animal for the study of luteal function and luteolysis, and a local uterine luteolytic mechanism involving prostaglandin (PG) F-2 $\alpha$ has 
been demonstrated in this species (review by Horton \& Poyser, 1976). However, published data on ovarian blood flow in the guinea-pig are confined to the reports of Sjoquist, Bjellin \& Carter (1977) on total ovarian flow on Days 1 and 11 of the oestrous cycle, and of Bjellin, Sjoquist \& Carter (1975) on total ovarian flow between Days 22 and 66 of pregnancy. No data are available on luteal flow, or on the progression of changes in flow during luteal regression.

This paper reports a radioactive microsphere study of ovarian and luteal blood flow rates throughout the oestrous cycle of the guinea-pig, together with data on peripheral plasma progesterone levels. Particular attention was paid to changes that occurred during luteal regression.

\section{Materials and Methods}

Blood flow

The 35 virgin female guinea-pigs used were of the Dunkin-Hartley strain and weighed 400$730 \mathrm{~g}$. They were housed in wire-mesh cages, and fed a commercial pelleted diet and water ad libitum. All animals had had at least 2 consecutive oestrous cycles of 15-19 days in the period immediately before blood flow measurement.

Oestrous cycles were studied by daily observation for vaginal opening, and vaginal smears were taken, and stained with Giemsa, on days when the vagina was perforate. The first day of complete vaginal opening when the smear contained abundant cornified epithelial cells with very few nucleated epithelial cells or leucocytes was designated Day 1 of the cycle. The mean duration of the oestrous cycle in these guinea-pigs was 16.5 days.

General anaesthesia was induced by the intraperitoneal injection of sodium pentobarbitone at a dose rate of $30 \mathrm{mg} / \mathrm{kg}$ body weight. Additional local anaesthesia with $2 \%$ lignocaine hydrochloride was used if necessary.

The right common carotid artery and both femoral arteries were catheterized with heparinized polyethylene catheters filled with saline $(9 \mathrm{~g} \mathrm{NaCl} / \mathrm{l})$. The carotid and one of the femoral catheters were connected to a pressure transducer, and arterial pressure was recorded throughout the experiments. The tip of the catheter in the right common carotid artery was positioned in the left ventricle with the aid of pressure measurements, its position being confirmed by subsequent dissection. The other femoral catheter was used for blood sampling. The microspheres were $15 \pm 3 \mu \mathrm{m}$ in diameter and were labelled with ${ }^{85} \mathrm{Sr}$ (3M Co., St Paul, Minnesota). A dose of $400000-600000$, suspended in $0.5-0.7 \mathrm{ml} 0.9 \%$ saline, was infused with a $1 \mathrm{ml}$ tuberculin syringe through the carotid catheter into the left ventricle during a period of $30 \mathrm{sec}$. To ensure even mixing, the hand holding the syringe was placed on a vortex mixer while injecting, thus keeping the suspension in continuous agitation. Starting $10 \mathrm{sec}$ before and continuing until $20 \mathrm{sec}$ after the microsphere injection, a reference sample of blood was withdrawn with the aid of a perfusion pump (Perfusor: B. Braun, Melsungen) at a constant rate of $1.1 \mathrm{ml} \cdot \mathrm{min}^{-1}$ from one of the femoral arteries. The animal was then killed with an intraperitoneal overdose of sodium pentobarbitone. Both the ovaries and a portion of each kidney were dissected free from connective tissue and fat, blotted, weighed and placed into counting tubes. The radioactivity in the contents of the ovaries, kidneys, and reference sample of blood, and that of the $1 \mathrm{ml}$ syringe, was measured using an automatic scintillation spectrometer, (Packard Tri-Carb, Model 3002). In 2 animals on Day 10 of the cycle, samples of lung tissue were also counted. After the first counting was completed the corpora lutea were dissected from the ovaries, pooled, weighed and their radioactive content counted.

The number of microspheres injected into each experimental animal was calculated as follows. The mean radioactivity per sphere was calculated by counting the total number of spheres in each of a series of small samples of measured radioactivity. At the time of each experiment, a second sample of microspheres equal in volume to that to be injected was with- 
drawn into an identical syringe. This second sample was subsequently expelled into a counting tube and its radioactivity determined. From this count the total number of spheres in the injected sample was calculated. The syringe used for injection of spheres, and that used for the second sample, were also counted in the spectrometer to obtain a measure of the number of spheres remaining in these syringes.

Organ blood flows were calculated from their content of ${ }^{85} \mathrm{Sr}$ relative to that of the reference sample of blood using the formula described by Bjellin et al. (1975). Cardiac output was calculated according to the formula described by Hales (1974).

The data were analysed by analysis of variance and the Student-Newman-Keuls procedure (Sokal \& Rohlf, 1969).

\section{Progesterone}

Peripheral plasma progesterone levels were measured in 37 guinea-pigs selected in the same way as in the blood flow experiment, on the same days of the oestrous cycle. Under sodium pentobarbitone anaesthesia, arterial blood was collected via a polyethylene carotid cannula into heparinized tubes. This blood was centrifuged for $15-20 \mathrm{~min}$ at $1800 \mathrm{~g}$ and $4^{\circ} \mathrm{C}$, and the plasma was aspirated and stored in sealed glass vials at $-20^{\circ} \mathrm{C}$ for periods up to 12 weeks before assay.

Radioimmunoassay. Antiserum raised in a sheep against progesterone-11-hemisuccinateBSA was obtained from the Hormone Assay Development Group (CSIRO, Prospect, New South Wales, Australia); significant cross-reactants were $11 \beta$-hydroxyprogesterone $(27 \%)$ and corticosterone $(5 \cdot 8 \%)$. Tritiated progesterone $\left[1,2,6,7-{ }^{3} \mathrm{H}\right]$ progesterone (sp. act. $82 \mathrm{Ci} / \mathrm{mmol}$ ) was obtained from New England Nuclear, Massachusetts, U.S.A. The buffer used in the assay was $0.01 \mathrm{M}$-phosphosaline containing $0.02 \% \mathrm{Na}_{2}$ EDTA, $0.02 \%$ bovine gamma-globulin and $0.03 \%$ sodium azide.

Aliquots $(100 \mu \mathrm{l})$ of plasma were extracted with $2 \mathrm{ml}$ hexane (Analar). The solvent phase was removed to assay tubes and the hexane evaporated under nitrogen at $30^{\circ} \mathrm{C}$. Solvent residues were reconstituted in $400 \mu \mathrm{l}$ assay buffer. Antiserum (100 $\mu \mathrm{l}$; initial dilution 1/3000) and $\left[{ }^{3} \mathrm{H}\right]$ progesterone $(100 \mu \mathrm{l} ; 70 \mathrm{pg} /$ tube $)$ were added to the sample and standard tubes and incubated overnight at $4^{\circ} \mathrm{C}$. Free and bound hormone were separated by the addition of $100 \mu \mathrm{l}$ charcoal $(0.3 \%)$ coated with dextran $(0.03 \%)$, in suspension. After centrifugation at $1500 \mathrm{~g}$ for $10 \mathrm{~min}$ the supernatants were decanted into vials for counting.

For each assay the recovery of $\left[{ }^{3} \mathrm{H}\right]$ progesterone $(200$ c.p.m.) from plasma was measured in 10 samples. Assay values were then corrected for mean extraction recovery. In 25 assays the mean \pm s.e.m. recovery was $86 \cdot 3 \pm 2 \cdot 4 \%$.

Assay results were calculated by the method of Burger, Lee \& Rennie (1972). Assay sensitivity was $0.05 \mathrm{ng} / \mathrm{ml}$. Plasma pools obtained from 1 wether and 2 ewes were included in each assay; mean \pm s.e.m. values for these pools were $0.03 \pm 0.01,2.4 \pm 0.11$ and $4.2 \pm 0.19$ $\mathrm{ng} / \mathrm{ml}(n=54)$ respectively. Within-assay variation was $15.9 \pm 1.3 \%$ (s.e.m.; $n=54)$ at 0.7 $\mathrm{ng} / \mathrm{ml}$.

\section{Results}

\section{Blood flow}

Mean ( \pm s.d.) arterial pressure was $60.8 \pm 3.1 \mathrm{mmHg}$ at the time of injection of microspheres, and cardiac output was $134.7 \pm 9.7 \mathrm{ml} \cdot \mathrm{min}^{-1}$, with no significant variation between groups. There was a close correlation between blood flow to the left and right kidneys $(r=0.95)$, indicating an even distribution of microspheres. Radioactivity in lung tissue was extremely low, being only marginally higher than background levels. 
Table 1. Mean \pm s.d. weights of the ovaries and corpora lutea (CL) in guinea-pigs (5/group) on various days of the oestrous cycle

\begin{tabular}{ccccc}
\hline Day of cycle & $\begin{array}{c}\text { Weight of single ovary } \\
(\mathrm{mg})\end{array}$ & $\begin{array}{c}\text { Weight of single CL } \\
(\mathrm{mg})\end{array}$ & Mean no. of CL/ovary & $\begin{array}{c}\text { Wt of CL as proportion of } \\
\text { ovarian weight (\%) }\end{array}$ \\
\hline 6 & $44.6 \pm 8.2$ & $2.88 \pm 0.6^{*}$ & 1.5 & 10 \\
9 & $49.8 \pm 6.2$ & $4.07 \pm 0.8$ & 1.7 & 14 \\
10 & $46.6 \pm 7.0$ & $4.01 \pm 0.2$ & 1.6 & 14 \\
12 & $44.0 \pm 3.9$ & $3.71 \pm 0.4$ & 1.7 & 9 \\
14 & $57.9 \pm 8.8$ & $3.58 \pm 0.6$ & 1.5 & 8 \\
16 & $46.1 \pm 6.8$ & $1.91 \pm 0.2^{* *}$ & 1.8 & 5 \\
1 & $37.5 \pm 8.8$ & $1.34 \pm 0.1^{* *}$ & 1.3 &
\end{tabular}

Significant variations between individual groups are shown as differences from Days 9, 10, 12 and 14: ${ }^{*} P<0.05 ;{ }^{* *} P<0.01$.

$\dagger$ Significant between-group variation $(P<0.001)$.

Ovarian weight did not vary significantly throughout the cycle (Table 1), whereas luteal weight rose between Days 6 and 9 and had fallen significantly by Day 16, declining slightly further by Day 1 of the following cycle $(P<0.01)$. Luteal weight as a proportion of ovarian weight reached a maximum between Days 9 and 12 .

The highest mean flow rate in ovaries and corpora lutea was observed on Day 10, but no significant differences were demonstrated between Days 9, 10,12 or 14 (Table 2). Ovarian flow was lower on Day 6 than on Days 9, 10 or $12(P<0.05)$ and luteal flow lower on Day 6 than Days 9 or $10(P<0.05)$. Both ovarian and luteal flow rates had fallen by Day 16, remaining low on Day 1. Although luteal weight never exceeded $14 \%$ of ovarian weight (Table 1), the proportion of ovarian blood flow going to the corpora lutea was about $70 \%$ between Days 9 and 12, falling sharply after Day 14. Mean total flow to a single ovary, as a percentage of cardiac output, reached a maximum of $0.19 \%$ at Day 10 and a minimum of $0.03 \%$ at Day 16 . The total luteal tissue per ovary received a maximum of $0.15 \%$ and a minimum of $0.02 \%$ on the same days.

Table 2. Mean \pm s.d. ovarian and luteal blood flow in guinea-pigs (5/group) on various days of the oestrous cycle

\begin{tabular}{cccc}
\hline Day of cycle & $\begin{array}{c}\text { Blood flow per } \\
\text { ovary } \dagger \\
\left(\mathrm{ml} \cdot \mathrm{min}^{-1}\right)\end{array}$ & $\begin{array}{c}\text { Blood flow per } \\
\text { corpus luteum } \\
\left(\mathrm{ml} \cdot \mathrm{min}^{-1}\right)\end{array}$ & $\begin{array}{c}\text { Total luteal blood flow } \\
\text { as proportion of } \\
\text { total ovarian flow } \\
(\%)\end{array}$ \\
\hline 6 & $0.07 \pm 0.02$ & $0.04 \pm 0.02$ & 66 \\
9 & $0.17 \pm 0.06$ & $0.07 \pm 0.03$ & 76 \\
10 & $0.21 \pm 0.07$ & $0.10 \pm 0.04$ & 69 \\
12 & $0.18 \pm 0.07$ & $0.07 \pm 0.03$ & 68 \\
14 & $0.14 \pm 0.03$ & $0.06 \pm 0.03$ & 65 \\
16 & $0.04 \pm 0.01^{*} \ddagger$ & $0.01 \pm 0.002^{*}$ & 44 \\
1 & $0.07 \pm 0.04^{*} \ddagger$ & $0.01 \pm 0.005^{*}$ & 18 \\
\hline
\end{tabular}

* Significant variations between individual groups are shown as differences from Days $9,10,12$ and $14, P<0 \cdot 01$.

$\dagger$ Significant between-group variation $(P<0.001)$.

$\ddagger$ Difference between Days 12 and 16, and Days 14 and $1: P<0.05$.

Luteal flow was highest between Days 9 and 12, when it exceeded the combined stromal and follicular flow rates more than 10-fold (Table 3). Although stromal and follicular flow rates were variable between groups, this variation was not significant. Flow to the total ovarian and luteal tissues had fallen by Day 16 and showed no further significant change on Day 1 of the following cycle. Although mean ovarian and luteal flow rates were lower on Day 14 than on Days 9, 10 or 12 , these differences were not significant $(P>0.05)$. 
Table 3. Relative blood flow (mean \pm s.d.) to the whole ovary, follicles and stroma, and corpora lutea in guinea-pigs (5/group) on various days of the oestrous cycle

\begin{tabular}{cccc}
\hline & \multicolumn{3}{c}{ Blood flow $\left(\mathrm{ml} \cdot \mathrm{min}^{-1} \cdot \mathrm{g}^{-1}\right)$} \\
\cline { 2 - 4 } Day of cycle & Whole ovary $\dagger$ & Follicles and stroma & Corpora lutea $\dagger$ \\
\hline 6 & $1.93 \pm 1.4$ & $0.66 \pm 0.35$ & $13 \cdot 72 \pm 9.9$ \\
9 & $3.80 \pm 1.4$ & $1.17 \pm 0.73$ & $20.48 \pm 8.9$ \\
10 & $5.84 \pm 1.2$ & $1.39 \pm 0.97$ & $24 \cdot 26 \pm 9 \cdot 3$ \\
12 & $4.55 \pm 1.6$ & $1.42 \pm 0.64$ & $19.74 \pm 9.4$ \\
14 & $2.40 \pm 0.6$ & $0.90 \pm 0.23$ & $17 \cdot 71 \pm 7.4$ \\
16 & $0.79 \pm 0.2^{* *} \ddagger$ & $0.48 \pm 0.20$ & $4.55 \pm 1.3^{* *}$ \\
1 & $1.83 \pm 0.9^{*}$ & $1.57 \pm 0.91$ & $7.75 \pm 4.1^{*}$ \\
\hline
\end{tabular}

Significant variations between individual groups are shown as differences from Days $9,10,12$ and $14:^{*} P<0.05,{ }^{* *} P<0.01$.

$\dagger$ Significant between-group variation $(P<0.001)$.

$\ddagger$ Difference between Days 14 and $16, P<0.05$.

\section{Progesterone}

Peripheral plasma progesterone levels on the same days of the oestrous cycle as the blood flow measurements are shown in Table 4. Since only small numbers were included in the groups on Days 6, 9 and 10 of the cycle, statistical analysis was confined to Days $12,14,16$ and Day 1 of the following cycle. Between-group variation was significant in these 4 groups $(P<0.001)$. Progesterone levels were lower on Days 14, 16 and 1 than on Day 12, and lower on Day 1 than Day $14(P<0.05)$.

Table 4. Peripheral plasma progesterone levels (mean \pm s.d.) in guinea-pigs on various days of the oestrous cycle

\begin{tabular}{ccc}
\hline Day of cycle & No. of animals & $\begin{array}{c}\text { Progesterone conc. } \\
(\mathrm{ng} / \mathrm{ml})\end{array}$ \\
\hline 6 & 3 & $2 \cdot 26 \pm 0.4$ \\
9 & 3 & $3.21 \pm 1.0$ \\
10 & 3 & $2.75 \pm 0.4$ \\
12 & 7 & $3.66 \pm 1 \cdot 1$ \\
14 & 7 & $2.11 \pm 1.4^{*}$ \\
16 & 7 & $1.09 \pm 0.8^{* *}$ \\
1 & 7 & $0.74 \pm 0.5^{* *}$ \\
\hline
\end{tabular}

Values significantly different from that on Day 12 , ${ }^{*} P<0.05,{ }^{* *} P<0.01$.

\section{Discussion}

The identification of PGF-2 $\alpha$ as a luteolytic hormone of uterine origin in the guinea-pig is now supported by a large amount of evidence (review by Horton \& Poyser, 1976). However, the mechanism(s) by which luteolysis is brought about remains uncertain, and a reduction in luteal blood flow has been recognized as a possible mode of action (Goldberg \& Ramwell, 1975; Horton \& Poyser, 1976; Ahrén, Herlitz, Janson, Khan \& Rosberg, 1976).

From the data presented here it is clear that luteal weight, blood flow and progesterone secretion in guinea-pigs remained at high levels until at least Day 12 of the oestrous cycle, and 
had fallen considerably by Day 16 . There was no evidence to suggest that the fall in luteal blood flow preceded that in progesterone secretion, and it was only in relation to progesterone that any significant fall was demonstrable by Day 14. These data therefore do not support the idea that declining luteal blood flow is an initiating mechanism in functional luteal regression in this species.

Nevertheless, blood flow did fall rapidly and substantially during the period when progesterone secretion was declining, and a causal role for vascular changes in the progression of luteolysis can not be excluded. Evidence from many studies has shown that the effects of PGF-2 $\alpha$ in vivo in producing complete functional and structural luteolysis have not generally been repeatable in vitro (Goldberg \& Ramwell, 1975; Ahrén et al., 1976). A possible explanation of the apparent discrepancies between in-vivo and in-vitro studies would be that in vivo any direct effects of PGF- $2 \alpha$ on the luteal cells are supplemented by additional primary or secondary effects on the luteal vasculature, which in turn influence the progression of the luteolytic process.

Limitations on the ability of the radioactive microsphere method to measure local tissue blood flow levels with accuracy have been discussed by Buckberg et al. (1971) and Hales (1974). These authors, and others working with ovarian blood flow in small animals (Janson \& Selstam, 1975; Janson \& Albrecht, 1975), have concluded that the method offers reasonable accuracy when the number of spheres trapped in each tissue compartment to be studied is not less than about 400 . This number would have been reached or exceeded consistently in the whole ovaries and pooled corpora lutea in this study between Days 9 and 14 of the cycle. However, stromal and follicular flow levels at all stages of the cycle, and ovarian and luteal flow levels after Day 14, were so low that the number of spheres per compartment was below 400 . Thus the accuracy of flow measurement in these samples was presumably reduced. One further possible source of error would be shunting of spheres through the ovary via arterio-venous connections greater than $15 \mu \mathrm{m}$ in diameter. This is unlikely to have been substantial in the present study in view of the very low levels of radioactivity in lung tissue, although these measurements were made on Day 10 only.

Quantitatively, the absolute ovarian blood flows measured in this study were consistent with those reported by Sjoquist et al. (1977) on Days 1 and 11 of the cycle in the guinea-pig, and the relative ovarian flows during the luteal phase of the cycle were also similar to results from cyclic (Mattner \& Thorburn, 1969) and pregnant (Rosenfeld, Morriss, Makowski, Meschia \& Battaglia, 1974) sheep. Relative luteal flows between Days 9 and 12 of the cycle in guinea-pigs were also similar to those in pregnant (Abdul Karim \& Bruce, 1973) and pseudopregnant (Janson \& Albrecht, 1975) rabbits, but were higher than those in cyclic sheep (Thorburn \& Hales, 1972).

In common with the guinea-pig, the sheep has an oestrous cycle of about 17 days and a uterine luteolytic mechanism mediated by PGF-2 $\alpha$ (McCracken et al., 1972). Luteal regression in sheep (Deane, Hay, Moor, Rowson \& Short, 1966) also begins at approximately the same stage of the cycle as in the guinea-pig. However, the rate of fall in plasma progesterone (Thorburn, Bassett \& Smith, 1969; Baird, Land, Scaramuzzi \& Wheeler, 1976; Pant, Hopkinson \& Fitzpatrick, 1977) and luteal blood flow (Niswender et al., 1975; Bruce \& Moor, 1976) in sheep appears to be more rapid than in the guinea-pig. Similarly, structural regressive changes in the corpus luteum of the sheep (Deane et al., 1966) appear to progress more rapidly than in the guinea-pig (Hossain \& O'Shea, 1977).

The progesterone levels in guinea-pigs recorded during the luteal phase of the cycle in this study were similar to those reported by Challis, Heap \& Illingworth (1971), and Blatchley, Donovan \& ter Haar (1976), but lower than those of Heap, Perry \& Rowlands (1967), who used a fluorometric assay. However, Challis et al. (1971) reported that the fall in plasma progesterone values during luteal regression was evident at Day 10, earlier than in the present study. The reason for this difference is not clear, although differences between the strains of 
guinea-pigs used, or methods of dating the start of the cycle, may have contributed. We also failed to detect the progesterone surge at Day 1 which was reported by Croix \& Franchimont (1975) and Blatchley et al. (1976).

We thank Dr S. L. Skinner (Department of Physiology) for the loan of the perfusion pump, Dr K. J. Fahey (C.S.I.R.O.) for the use of the spectrometer, and Dr R. G. Beilharz, Dr A. H. Brook and Dr N. W. Bruce for helpful advice. Guinea-pigs were donated by the Commonwealth Serum Laboratories, Melbourne, and this project was supported by the Melbourne University Veterinary Research Fund.

\section{References}

Abdul Karim, R.W. \& Bruce, N.W. (1973) Blood flow to the ovary and corpus luteum at different stages of gestation in the rabbit. Fert. Steril. 24, 44- 47.

Ahrén, K., Herlitz, H., Janson, P.O., Khan, M.I. \& Rosberg, S. (1976) Control of luteal function. Proc. 5th Int. Congr. Endocr. (Int. Congr. Ser. No. 402), Vol. 1, pp. 324-329. Excerpta Medica, Amsterdam.

Baird, D.T. (1974) Prostaglandin F-2 $\alpha$ and ovarian blood flow in sheep. J. Endocr. 62, 413-414.

Baird, D.T., Land, R.B., Scaramuzzi, R.J. \& Wheeler, A.G. (1976) Endocrine changes associated with luteal regression in the ewe; the secretion of ovarian oestradiol, progesterone and androstenedione and uterine prostaglandin F-2 $\alpha$ throughout the oestrous cycle. J. Endocr. 69, 275-286.

Bjellin, L., Sjoquist, P.O.B. \& Carter, A.M. (1975) Uterine, maternal placental and ovarian blood flow throughout pregnancy in the guinea-pig. Z. Geburtsh. Perinat. 179, 179-187.

Blatchley, F.R., Donovan, B.T. \& ter Haar, M.B. (1976) Plasma progesterone and gonadotrophin levels during the estrous cycle of the guinea pig. Biol. Reprod. 15, 29-38.

Bruce, N.W. \& Hillier, K. (1974) The effect of prostaglandin F-2 $\alpha$ on ovarian blood flow and corpora lutea regression in the rabbit. Nature, Lond. 24, 176177.

Bruce, N.W. \& Moor, R.M. (1976) Capillary blood flow to ovarian follicles, stroma and corpora lutea of anaesthetized sheep. J. Reprod. Fert. 46, 299-304.

Buckberg, G.D., Luck, J.C., Payne, D.B., Hoffman, J.I.E., Archie, J.P. \& Fixler, D.E. (1971) Some sources of error in measuring regional blood flow with radioactive microspheres. $J$. appl. Physiol. 31, 598-604.

Burger, H.G., Lee, V.W.K. \& Rennie, G.C. (1972) A generalized computer program for the treatment of data from competitive protein-binding assays including radioimmunoassays. J. Lab. Clin. Med. 80, 302312.

Challis, J.R.G., Heap, R.B. \& Illingworth, D.V. (1971) Concentrations of oestrogen and progesterone in the plasma of non-pregnant, pregnant and lactating guinea pig. J. Endocr. 51, 333-345.

Croix, D. \& Franchimont, P. (1975) Changes in the serum levels of the gonadotrophins, progesterone and oestradiol during the oestrous cycle of the guinea pig. Neuroendocrinology 19, 1-11.
Deane, H.W., Hay, M.F., Moor, R.M., Rowson, L.E.A. \& Short, R.V. (1966) The corpus luteum of the sheep: relationships between morphology and function during the oestrous cycle. Acta endocr., Copenh. 51, 245-263.

Goldberg, V.J. \& Ramwell, P.W. (1975) Role of prostaglandins in reproduction. Physiol. Rev. 55, 325-351.

Hales, J.R.S. (1974) Radioactive microsphere techniques for studies of the circulation. Clin. exp. Pharmac, Physiol. Suppl. 1, 31-46.

Heap, R.B., Perry, J.S. \& Rowlands, I.W. (1967) Corpus luteum function in the guinea pig; arterial and luteal progesterone levels, and the effects of hysterectomy and hypophysectomy. J. Reprod. Fert. 13, 537553.

Horton, E.W. \& Poyser, N.L. (1976) Uterine luteolytic hormone; a physiological role for prostaglandin $\mathrm{F}$ 2a. Physiol. Rev. 56, 595-651.

Hossain, M.I. \& O'Shea, J.D. (1977) Luteal regression in the guinea pig. Theriogenology 8, 142, Abstr.

Janson, P.O. \& Albrecht, A.I. (1975) Methodological aspects of blood flow measurement in ovaries containing corpora lutea. J. appl. Physiol. 38, 288293.

Janson, P.O. \& Selstam, G. (1975) A comparison between direct and indirect measurements of blood flow in the follicular ovary of the rabbit. Acta physiol. scand. 94, 1-7.

Mattner, P.E. \& Thorburn, G.D. (1969) Ovarian blood flow in sheep during the oestrous cycle. J. Reprod. Fert. 19, 547-549.

McCracken, J.A., Glew, M.E. \& Scaramuzzi, R.J. (1970) Corpus luteum regression induced by prostaglandin F-2 $\alpha$. J. clin. Endocr. Metab. 30, 544-546.

McCracken, J.A., Carlson, J.C., Glew, M.E., Goding, J.R., Baird, D.T., Green, K. \& Samuelsson, B. (1972) Prostaglandin F-2 $\alpha$ identified as a luteolytic hormone in sheep. Nature, New Biol. 238, 129-134.

Niswender, G.D., Diekman, M.A., Nett, T.M. \& Akbar, A.M. (1973) Relative blood flow to the ovaries of cycling and pregnant ewes. Biol. Reprod. 9, 87.

Niswender, G.D., Moor, R.T., Akbar, A.M., Nett, T.M. \& Diekman, M.A. (1975) Flow of blood to the ovaries of ewes throughout the estrous cycle. Biol. Reprod. 13, 381-388.

Niswender, G.D., Reimers, T.J., Diekman, M.A. \& Nett, T.M. (1976) Blood flow: a mediator of ovarian function. Biol. Reprod. 14, 64-81. 
Novy, M.J. (1972) Distribution of ovarian blood flow in rabbits as measured by radioactive microspheres. Biol. Reprod. 7, 105-106.

Pant, H.C., Hopkinson, C.R.N. \& Fitzpatrick, R.J. (1977) Concentration of oestradiol, progesterone, luteinizing hormone and follicle-stimulating hormone in the jugular venous plasma of ewes during the oestrous cycle. J. Endocr. 73, 247-255.

Pharriss, B.B. \& Wyngarden, L.J. (1969) The effect of prostaglandin F-2a on progestogen content of ovaries from pseudopregnant rats. Proc. Soc. exp. Biol. Med. 130, 92-94.

Rathmacher, R.P. \& Anderson, L.L. (1968) Blood flow and progesterone levels in the ovary of cycling and pregnant pigs. Am. J. Physiol. 214, 1014-1018.

Rosenfeld, C.R., Morriss, F.H., Makowski, E.L., Meschia, G. \& Battaglia, F.C. (1974) Circulatory changes in the reproductive tissues of ewes during pregnancy. Gynecol. Invest. 5, 252-268.
Sjoquist, P.O.B., Bjellin, L. \& Carter, A.M. (1977) Blood flow to the genital tract of oestrous and dioestrous guinea pigs. J. Reprod. Fert. 51, 83-86.

Sokal, R.R. \& Rohlf, F.J. (1969) Biometry. W. H. Freeman and Company, San Francisco.

Thorburn, G.D. \& Hales, J.R.S. (1972) Selective reduction in blood flow to the ovine corpus luteum after infusion of prostaglandin F-2 $\alpha$ into a uterine vein. Proc. Aust. Physiol. Pharmac. Soc. 3, 145, Abstr.

Thorburn, G.D., Bassett, J.M. \& Smith, I.D. (1969) Progesterone concentrations in the peripheral plasma of sheep during the oestrous cycle. J. Endocr. 45, 459469 .

Received 25 January 1979 